\title{
Reduced expression of Axin correlates with tumour progression of oesophageal squamous cell carcinoma
}

\author{
M Nakajima*,', M Fukuchi', T Miyazaki', N Masuda', H Kato' and H Kuwano' \\ 'Department of Surgery I, Gunma University Faculty of Medicine, 3-39-22 Showa-machi, Maebashi, Gunma 37 I-85 II, Japan
}

Axin is a negative regulator of the Wnt signalling pathway, and genetic alterations of AXIN/ have been suggested to be an important factor of carcinogenesis in some tumours. The objective of this study was to clarify the clinicopathologic and prognostic significance of Axin in oesophageal squamous cell carcinoma (SCC). Immunohistochemical staining for Axin was performed on surgical specimens obtained from 81 patients with oesophageal SCC. Western and Northern blottings were performed on proteins and RNA from oesophageal SCC cell lines. Then polymerase chain reaction-single-strand conformational analysis (PCR-SSCP) was performed on DNA from oesophageal SCC patients and cell lines. Axin expression was found to be correlated inversely with depth of invasion, lymph node metastasis, and lymphatic invasion. Although univariate analysis showed Axin to be a negative predictor, multivariate analysis showed that it was not an independent prognostic marker. In all but one of the seven cell lines examined, the levels of protein expression were equivalent to RNA expression. PCR-SSCP showed that five patients and three cell lines had polymorphisms in exon 4 or 5 of the AXINI gene, but none of the 8 I patients with oesophageal SCC had mutations. Our findings suggest that reduced expression of Axin is correlated with tumour progression of oesophageal SCC. However, additional studies will be necessary to elucidate the mechanism responsible for loss of Axin expression in tumour cells.

British Journal of Cancer (2003) 88, 1734- 1739. doi:I0.1038/sj.bjc.660094 I www.bjcancer.com

(C) 2003 Cancer Research UK

Keywords: Axin; oesophageal squamous cell carcinoma; carcinogenesis; immunohistochemistry; single nucleotide polymorphism

The Wnt signalling pathway regulates cellular proliferation, differentiation, morphology, and motility in vertebrates and invertebrates (Zeng, 1997; Akiyama, 2000; Bienz and Clevers, 2000). Axin, a negative regulator of this pathway, promotes phosphorylation of serine/threonine in exon 3 of $\beta$-catenin by forming a complex with adenomatous polyposis coli (APC) and glycogen synthase kinase-3 $\beta$ (GSK-3 $\beta$ ) (Ikeda et al, 1998, 2000; Kishida et al, 1998). Phosphorylated $\beta$-catenin is quickly degraded via a ubiquitin-proteasome pathway in the cytoplasm (Nakamura, 1997). Upon Wnt signalling, because the activity of Axin complex is blocked through Dishevelled, phosphorylation of $\beta$-catenin is suppressed and $\beta$-catenin accumulates in the cytoplasm. Accumulated $\beta$-catenin protein is translocated to the nucleus as a coactivator for the T-cell factor (TCF)/lymphocyte enhancerbinding factor (LEF) family (Morin et al, 1997; He et al, 1998) and activates the transcription of Wnt target genes such as c-myc (He et al, 1998) or cyclin D1 (Tetsu and McCormick, 1999).

The wild-type Axin gene (AXIN1) is regarded as a tumour suppressor in some kinds of tumours. AXIN1 mutations have been reported in a colon carcinoma cell line (Webster et al, 2000), hepatocellular carcinoma (HCC) (Satoh et al, 2000; Laurent-Puig et al, 2001), ovarian endometrioid adenocarcinoma (Wu et al, 2001), and sporadic medulloblastoma (Dahmen et al, 2001). In HCC cell lines with AXIN1 mutations, accumulation of $\beta$-catenin in

*Correspondence: M Nakajima; E-mail: mnakajim@med.gunma-u.ac.jp Received 21 October 2002; revised 30 January 2003; accepted 10 February 2003 the cytoplasm or nucleus has been observed, and the transcription activity of TCF4 is regulated positively (Satoh et al, 2000).

Oesophageal carcinoma is one of the most lethal gastrointestinal malignancies. Despite recent advances in therapy and management, the overall 5-year survival rate remains at less than $50 \%$ (Ando et al, 1997; Collard et al, 2001). In future, it will be possible to identify prognostic markers and thus select the most suitable therapy for each tumour.

Although several studies have been performed to elucidate the relation between Axin expression and tumours in several organs, to our knowledge, there have been no reports related to immunohistochemical expression of Axin in oesophageal carcinoma, or the association between Axin expression and prognosis.

To clarify whether Axin expression is a significant prognostic factor, we examined immunohistochemically the relation between Axin expression, pathologic tumour variables, and prognosis in patients with oesophageal squamous cell carcinoma (SCC). Next, to clarify the mechanism of regulation of Axin expression, we performed Western and Northern blot analyses of oesophageal SCC cell lines. We also searched for mutations of AXIN1 that were considered to activate the Wnt signalling pathway.

\section{MATERIALS AND METHODS}

\section{Patients}

Surgical specimens were obtained from 81 patients (70 males and 11 females) with oesophageal SCC, who underwent potentially curative surgery at the Department of Surgery I, Gunma University 
Faculty of Medicine, between 1983 and 2000. The age range of the patients was $40-78$ years, and the mean age 61.3 years. Tumour stage and disease grade were classified according to the fifth edition of the TNM Classification of the International Union Against Cancer (UICC). None of the patients had received irradiation or chemotherapy before surgery, nor did any of them have haematogenic metastases at the time of surgery. Patients who underwent noncurative surgery and/or had inadequate follow-up were not included in the study. Postoperative chemotherapy and/or radiation therapy were not performed until recurrence of the tumour was confirmed by radiologic or endoscopic examination. All patients signed informed consent forms according to our institutional guidelines.

\section{Cell culture}

Seven human oesophageal SCC cell lines were grown on plastic tissue culture dishes: TE-series 1, 2, 8, 13, and 15 (gift from Dr T Nishihira, Tohoku University, Sendai, Japan) (Nishihira et al, 1993), and TT and TTn (JCRB0262 and 0261, gift from Dr K Takahashi, Tohoku University, Miyagi, Japan). The TE-series were cultured in RPMI 1640 medium (Sigma, St Louis, MO, USA) containing $10 \%$ foetal bovine serum and antibiotics $\left(100 \mathrm{U} \mathrm{ml}^{-1}\right.$ penicillin and $100 \mu \mathrm{g} \mathrm{ml}^{-1}$ streptomycin); TT and TTn were cultured in a 1:1 mixture of Dulbecco's modified Eagle medium and Ham's F-12 medium (Sigma) containing 10\% foetal bovine serum and antibiotics, as described above.

\section{Immunohistochemistry for Axin}

Resected specimens were fixed with $10 \%$ neutral-buffered formalin and embedded in paraffin blocks. Sections, $4 \mu \mathrm{m}$ thick, were deparaffinised with xylene, rehydrated, and incubated with fresh $0.3 \% \mathrm{H}_{2} \mathrm{O}_{2}$ in methanol for $30 \mathrm{~min}$ at room temperature. After rehydration through a graded ethanol series, tissue sections for the Axin study were autoclaved in $20 \mathrm{~mm}$ citric acid buffer at $120^{\circ} \mathrm{C}$ for $2 \mathrm{~min}$ and then cooled to $30^{\circ} \mathrm{C}$. After incubation with normal goat serum (Histofine SAB-PO (R) kit; Nichirei, Tokyo, Japan), the tissue sections were applied for $30 \mathrm{~min}$ and removed by blotting. The sections were then incubated overnight with primary rabbit anti-Axin polyclonal antibody (Zymed Laboratories Inc., San Francisco, USA) at a dilution of $1: 100$ in PBS containing $1 \%$ bovine serum albumin at $4{ }^{\circ} \mathrm{C}$, washed in PBS, and incubated with secondary antibody for $30 \mathrm{~min}$ at room temperature. Immunohistochemistry was performed with the SAB-PO (R) kit. The chromogen was $3,3^{\prime}$-diaminobenzidine tetrahydrochloride, applied as a $0.02 \%$ solution containing $0.0055 \% \mathrm{H}_{2} \mathrm{O}_{2}$ in $50 \mathrm{~mm}$ Tris- $\mathrm{HCl}$ buffer, $\mathrm{pH}$ 6.0. The sections were lightly counterstained with haematoxylin. Negative controls were prepared by substituting normal rabbit serum for each primary antibody, and no detectable staining was evident.

\section{Evaluation of Axin expression}

The mean Axin expression rate in the 81 primary tumours was almost $50 \%$. Therefore, when $50 \%$ or more of the tumour cells in a given specimen were positively stained to the same degree as normal epithelium, the sample was graded as Axin preserved. When fewer than $50 \%$ of the tumour cells were stained to the same degree as normal epithelium, the sample was graded as having reduced expression.

\section{Western blot analysis}

Protein extraction and immunoblotting were performed as described previously (Kain et al, 1994). Lysates from exponentially growing cell lines were prepared in a buffer containing $20 \mathrm{~mm}$ Tris$\mathrm{HCl}, \mathrm{pH} 7.5,150 \mathrm{~mm} \mathrm{NaCl}, 1 \%$ Nonidet P-40, $1 \%$ aprotinin and
$1 \mathrm{~mm}$ phenylmethylsulphonyl fluoride. The protein concentration was determined with a BCA Protein Assay Kit (Pierce, Rockford, IL, USA). In all, $30 \mu \mathrm{g}$ of protein from each cell line was resuspended in sodium dodecyl sulphate (SDS) sample buffer (100 mm Tris-HCl, pH 8.8; $0.01 \%$ bromophenol blue; $36 \%$ glycerol; $4 \%$ SDS) containing $1 \mathrm{~mm}$ dithiothreitol, boiled for $5 \mathrm{~min}$, and subjected to 5-20\% Ready Gels J (Bio-Rad, Tokyo, Japan). Proteins were electrotransferred to a Hybond enhanced chemiluminescence nitrocellulose membrane (Amersham Pharmacia Biotech, Buckinghamshire, UK). Proteins were immunoblotted with anti-rabbit Axin antibody (Zymed Laboratories Inc.), and bands were detected using an enhanced chemiluminescence detection system (Amersham Pharmacia Biotech). For reblotting, membranes were stripped according to the manufacturer's protocol. Anti- $\beta$-actin (Sigma) antibody served as the control.

\section{Northern blot analysis}

Total RNA was extracted from the cells with Trizol Reagent (Gibco BRL, Rockville, MD, USA). In all, $20 \mu \mathrm{g}$ of RNA per lane was electrophoresed in $1.2 \%$ agarose gels containing $2.2 \mathrm{moll}^{-1}$ formaldehyde, and blotted onto a Biodyne B membrane (Pall, Tokyo, Japan). The cDNA probe was labelled using a Random Primer DNA Labelling Kit (Roche Molecular Biochemicals, Mannheim, Germany) and $\left[\alpha_{-}{ }^{32} \mathrm{P}\right] \mathrm{dCTP}$ (Amersham Pharmacia Biotech). The rabbit Axin probe was digested from pcDNA3-FLAG/ rAxin (full-length) (gift from Dr A Kikuchi, Hiroshima University, Hiroshima, Japan). Membranes were prehybridised at $42^{\circ} \mathrm{C}$ for more than $2 \mathrm{~h}$ and hybridised overnight at $42^{\circ} \mathrm{C}$ after staining with methylene blue to verify the quality and quantity of the RNA. The membranes were washed in $2 \times$ SSC, $0.1 \%$ SDS for $15 \mathrm{~min}$ and $0.2 \times$ SSC, $0.1 \%$ SDS for $15 \mathrm{~min}$ at $42^{\circ} \mathrm{C}$. The washed membrane was exposed to X-ray film under an intensifying screen. A human $18 \mathrm{~S}$ probe served as the control.

\section{DNA extraction and polymerase chain reaction - single-strand conformational polymorphism (PCR - SSCP) analysis}

Small pieces of normal tissue and tumour tissue were frozen in liquid nitrogen and stored at $-80^{\circ} \mathrm{C}$ until DNA extraction. Highmolecular-weight DNA samples from seven oesophageal SCC cell lines, as well as fresh-frozen tumour and normal tissues from the 81 patients, were prepared by the phenol-chloroform method after treatment with SDS and proteinase K.

All samples were examined by PCR-SSCP analysis for mutations in exons 2-5 of AXIN1, which correspond to the binding sites of $\beta$-catenin and GSK-3 $\beta$. Each exon was amplified using the nine sets of PCR primers published previously (Satoh et al, 2000).

Each target sequence was amplified in a $20-\mu$ l reaction volume containing 10-20 ng of genomic DNA, $2 \mu \mathrm{M}$ dNTPs, $10 \mathrm{~mm}$ Tris$\mathrm{HCl}, \mathrm{pH} 8.3,50 \mathrm{~mm} \mathrm{KCl}, 2 \mathrm{mM} \mathrm{MgCl}_{2}, 0.2 \mu \mathrm{M}$ each primer, $1.5 \mu \mathrm{Ci}$ of $[\alpha-32 \mathrm{P}] \mathrm{dCTP}$ (Amersham Japan, Tokyo, Japan), and $1 \mathrm{U}$ of Taq DNA polymerase (Applied Biosystems, Foster City, CA, USA). These samples were amplified for 35 cycles of denaturation at $95^{\circ} \mathrm{C}$ for $30 \mathrm{~s}$, annealing at 60 or $61^{\circ} \mathrm{C}$ for $30 \mathrm{~s}$, and extension at $72^{\circ} \mathrm{C}$ for $1 \mathrm{~min}$. The PCR products were electrophoresed in 5\% polyacrylamide with $5 \%$ glycerol gels and autoradiographed for $24 \mathrm{~h}$ on Kodak XAR film (Eastman Kodak, Rochester, NY, USA).

\section{DNA sequencing}

DNA fragments were cut out of the dried gels and reamplified by PCR with the corresponding sets of primers for 40 cycles. Amplified DNA fragments were purified with a QIA quick PCR Purification Kit (QIAGEN, Hilden, Germany) and sequenced with an ABI PRISM 3100 (Applied Biosystems, Foster City, CA, USA). 
A
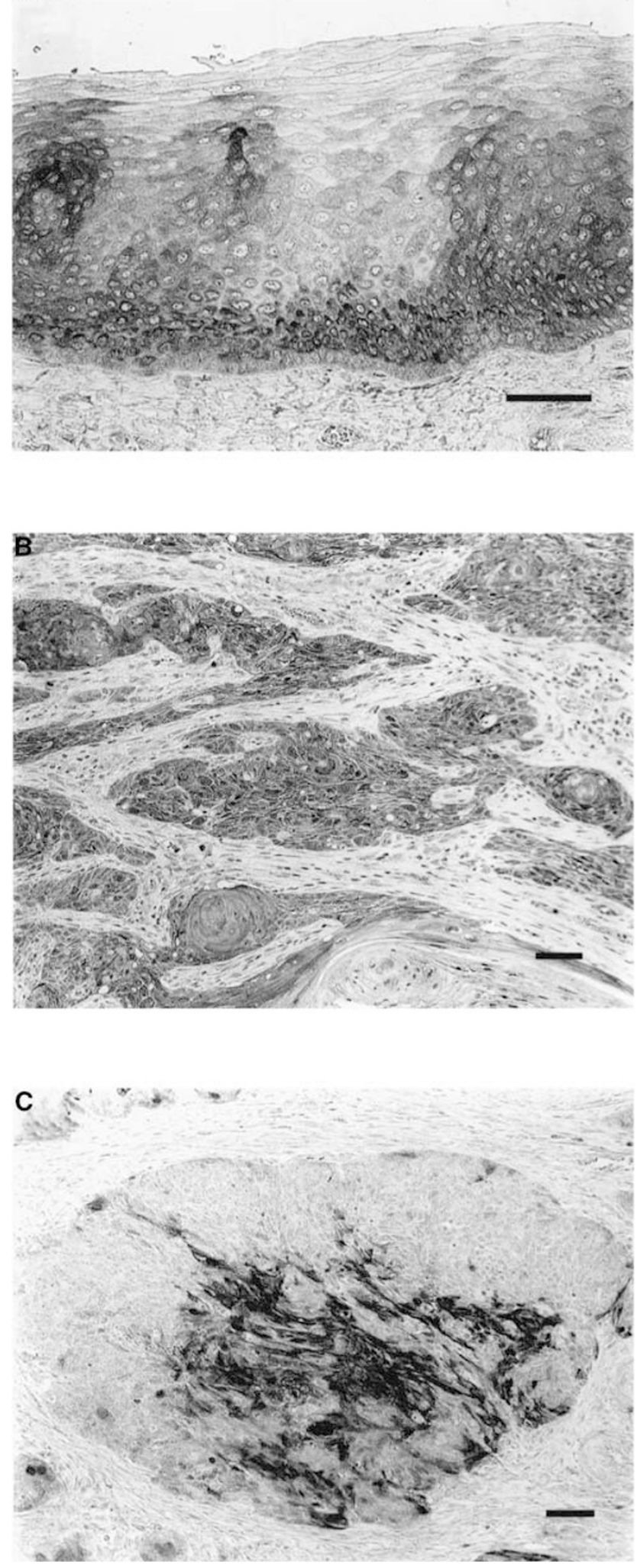

Figure I Photographs of tissue sections immunostained for Axin. (A) Axin was detected in the cytoplasm in normal oesophageal squamous epithelia. (B) Axin expression was highly preserved (Axin-preserved type). (C) Axin was partly detected in the cytoplasm in tumour cells, but expression partly disappeared in the peripheral cells of tumour nests (Axinreduced type). Black bar $=100 \mu \mathrm{m}$.

\section{Statistical analysis}

Statistical analysis was performed by the $\chi^{2}$ test, the Fisher exact test, and the Mann-Whitney $U$-test to assess the correlation between Axin immunohistochemical positivity and parameters. A Cox proportional hazards model for risk ratio was used to assess the simultaneous contribution of Axin expression to survival.

\section{RESULTS}

\section{Immunohistochemistry of Axin}

Immunoreactivity for Axin was strongly positive in normal stratified squamous epithelium of the oesophagus, and was localised in the cytoplasm (Figure 1A). Several staining patterns were observed for the expression of Axin in tumour tissues. Some tumours showed a diffuse decrease in Axin expression, others had both preserved and reduced expression in cell colonies, and others showed highly preserved expression (Figure 1B, C).

\section{Relation between Axin expression and clinicopathologic features}

The correlation between the clinicopathologic characteristics of patients with oesophageal SCC and the expression of Axin in their tumours is summarised in Table 1 . There were significant inverse correlations between Axin expression and depth of invasion $(P=0.0235)$, lymph node metastasis $(P=0.0255)$, and lymphatic invasion $(P=0.0058)$. However, there was no significant association with patient age, gender, tumour location, grade, pathologic stage, intraepithelial spread, or blood vessel invasion.

As a strong inverse correlation between Axin expression and lymphatic invasion was recognised, we examined the Axin status of tumour cells that had infiltrated lymph vessels. The result revealed that most of the cases positive for lymphatic invasion had reduced or no Axin expression (50 out of 56 cases).

\section{Prognostic significance of Axin expression}

To clarify whether Axin expression is a significant prognostic marker of patients with oesophageal SCC, univariate and multivariate survival analyses were performed. In univariate analyses by the Cox model, Axin negativity, pT classification, $\mathrm{pN}$ classification, pM classification, pStage, and lymphatic invasion were identified as negative predictors. In multivariate analyses, $\mathrm{pT}$ classification, but not Axin, was recognised as an independent prognostic factor (Table 2).

\section{Expression of Axin at the protein level in cultured cells}

Expression of Axin was characterised at the protein level in seven oesophageal SCC cell lines. Although all of these seven cell lines were originally derived from oesophageal SCC, Western blotting revealed different levels of Axin expression (Figure 2A). Axin was expressed at high levels in TE1, TE15, TT, and TTn, and there was very weak expression in TE2, TE8, and TE13.

\section{Expression of Axin at the mRNA level in cultured cells}

As there were marked variations in the level of expression of Axin protein in the cultured cell lines, Northern blotting was performed to examine the underlying mechanisms of the effects of Axin on tumour cell regulation. This analysis indicated that levels of mRNA expression were equivalent to levels of Axin protein expression, with the exception of the TE8 line, in which Axin expression was reduced in comparison with protein expression (Figure $2 \mathrm{~B}$ ). 
Table I Correlation between clinicopathologic characteristics and Axin expression

\begin{tabular}{|c|c|c|c|c|}
\hline \multirow[b]{2}{*}{ Parameters } & \multirow[b]{2}{*}{$n$} & \multicolumn{2}{|c|}{ Axin expression } & \multirow[b]{2}{*}{$P$-value } \\
\hline & & Reduced & Preserved & \\
\hline Age (mean \pm s.d., years) & & $61.3 \pm 8.5$ & $61.9 \pm 8.6$ & 0.7676 \\
\hline \multicolumn{5}{|l|}{ Gender } \\
\hline Male & 70 & 32 & 38 & \\
\hline Female & | | & 6 & 5 & 0.5853 \\
\hline \multicolumn{5}{|l|}{ Location } \\
\hline Cervical & 1 & 1 & 0 & \\
\hline Upper thoracic & 10 & 6 & 4 & \\
\hline Mid-thoracic & 50 & 23 & 27 & \\
\hline Lower thoracic & 20 & 8 & 12 & 0.3218 \\
\hline \multicolumn{5}{|l|}{ Grade } \\
\hline Well & 21 & 9 & 12 & \\
\hline Moderate & 39 & 15 & 24 & \\
\hline Poor & 21 & 14 & 7 & 0.1497 \\
\hline \multicolumn{5}{|l|}{ TNM classification } \\
\hline \multicolumn{5}{|l|}{$\mathrm{T}$} \\
\hline TI & 31 & 8 & 23 & \\
\hline $\mathrm{T} 2$ & 12 & 8 & 4 & \\
\hline T3 & 32 & 18 & 14 & \\
\hline T4 & 6 & 4 & 2 & $0.0235^{\mathrm{a}}$ \\
\hline \multicolumn{5}{|l|}{$N$} \\
\hline No & 34 & 11 & 23 & \\
\hline $\mathrm{NI}$ & 47 & 27 & 20 & $0.0255^{\mathrm{a}}$ \\
\hline \multicolumn{5}{|l|}{ M } \\
\hline MO & 66 & 29 & 37 & \\
\hline MI & 15 & 9 & 6 & 0.5136 \\
\hline \multicolumn{5}{|l|}{ Stage } \\
\hline 1 & 21 & 4 & 17 & \\
\hline$\| \mathrm{A}$ & 12 & 6 & 6 & \\
\hline$\| \mathrm{B}$ & 14 & 6 & 8 & \\
\hline III & 19 & 13 & 6 & \\
\hline IVA & 3 & 2 & 1 & \\
\hline IVB & 12 & 7 & 5 & 0.0750 \\
\hline \multicolumn{5}{|l|}{ Infiltrative growth pattern } \\
\hline$\alpha$ & 20 & 6 & 14 & \\
\hline$\beta$ & 56 & 29 & 27 & \\
\hline$\gamma$ & 5 & 3 & 2 & 0.2044 \\
\hline \multicolumn{5}{|l|}{ Intraepitherial spread } \\
\hline$(-)$ & 41 & 18 & 23 & \\
\hline$(+)$ & 40 & 20 & 20 & 0.5825 \\
\hline \multicolumn{5}{|l|}{ Lymphatic invasion } \\
\hline$(-)$ & 25 & 6 & 19 & \\
\hline$(+)$ & 56 & 32 & 24 & $0.0058^{a}$ \\
\hline \multicolumn{5}{|l|}{ Blood vessel invasion } \\
\hline$(-)$ & 46 & 20 & 26 & \\
\hline$(+)$ & 35 & 18 & 17 & 0.4775 \\
\hline
\end{tabular}

s.d. = standard deviation; ${ }^{\text {a }}$ Significant.

\section{Mutation of the AXIN1 gene in oesophageal SCC}

None of the 81 patients with oesophageal SCC had mutations, but five patients and three cell lines showed polymorphisms in the AXIN1 gene (Figure 3, Table 3).

We confirmed three previously published single-nucleotide polymorphisms (SNPs) (Lin et al, 2000; Dahmen et al, 2001). One polymorphism resulted in an amino-acid substitution, and the others were silent SNPs. However, there was no novel polymorphism or silent mutation.

\section{DISCUSSION}

Axin is a negative regulator of the Wnt signalling pathway. It accelerates phosphorylation and ubiquitination of $\beta$-catenin, thus inhibiting importation of $\beta$-catenin to the nucleus and controlling cell proliferation. Although an association of Axin with carcino-
Table 2 Univariate and multivariate analysis of Axin expression and pathologic factors

\begin{tabular}{|c|c|c|}
\hline Factors & Hazard ratio $\left(95 \% \mathrm{Cl}^{\mathrm{a}}\right)$ & $P$-value \\
\hline \multicolumn{3}{|l|}{ Univariate } \\
\hline Axin & $2.018(1.031-3.950)$ & $0.0405^{b}$ \\
\hline Gender & $0.483(0.147-1.581)$ & 0.2288 \\
\hline Age & $0.996(0.958-1.035)$ & 0.8206 \\
\hline Differentiation & $1.265(0.57 \mid-2.799)$ & 0.5624 \\
\hline pT classification & $8.245(2.889-23.527)$ & $<0.0001^{b}$ \\
\hline pN classification & $3.204(1.447-7.094)$ & $0.0041^{b}$ \\
\hline pM classification & $3.336(1.510-7.371)$ & $0.0029^{b}$ \\
\hline pStage classification & $8.338(1.996-34.842)$ & $0.0036^{b}$ \\
\hline Lymphatic invasion & $2.591(1.127-5.956)$ & $0.0250^{\mathrm{b}}$ \\
\hline Blood vessel invasion & $1.579(0.807-3.093)$ & 0.1824 \\
\hline \multicolumn{3}{|l|}{ Multivariate } \\
\hline Axin & $1.352(0.656-2.784)$ & 0.4137 \\
\hline pT classification & $5.930(1.36 \mid-25.848)$ & $0.0178^{b}$ \\
\hline pN classification & $1.503(0.488-4.628)$ & 0.4778 \\
\hline pM classification & $1.510(0.621-3.671)$ & 0.3636 \\
\hline pStage classification & $1.031(0.117-9.062)$ & 0.9783 \\
\hline Lymphatic invasion & $1.374(0.479-3.940)$ & 0.5549 \\
\hline
\end{tabular}

A TE1 TE2 TE8 TE13 TE15 TT TTn
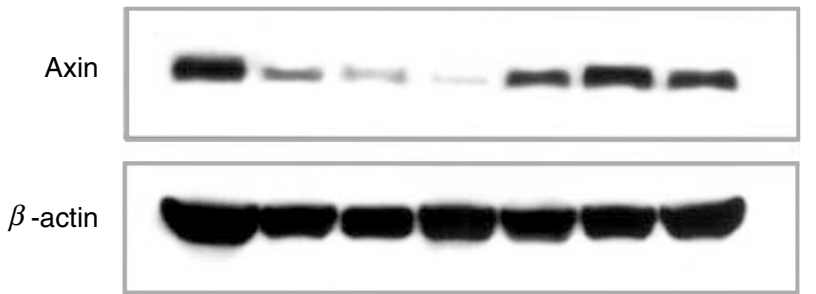

B

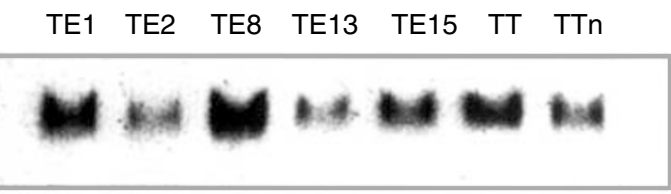

Axin

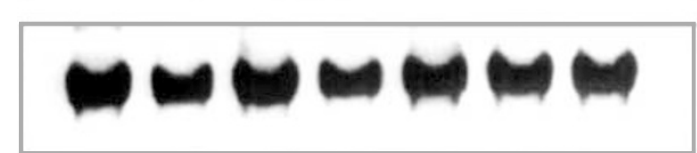

Figure 2 Western and Northern blotting of Axin in human oesophageal SCC cell lines. (A) Expression of Axin protein (top) and $\beta$-actin (bottom), as determined by Western blotting in various carcinoma cell lines. $\beta$-actin protein levels were used as controls for sample loading. (B) Expression of Axin mRNA as determined by Northern blotting. Top is Axin and bottom is I8S. mRNA expression is equivalent to protein expression except in the TE8 line. I8S was used as a control.

genesis has been reported in colon cancer cell lines (Webster et al, 2000), HCC (Satoh et al, 2000; Laurent-Puig et al, 2001) and medulloblastoma (Dahmen et al, 2001), to our knowledge there has been no report concerning oesophageal SCC. Therefore, we investigated the association between Axin expression and oesophageal SCC.

First, we performed an immunohistochemical study of the correlation between Axin expression and clinicopathologic factors in patients with oesophageal SCC. Axin expression was seen in the cytoplasm in normal oesophageal stratified squamous cells and 
A

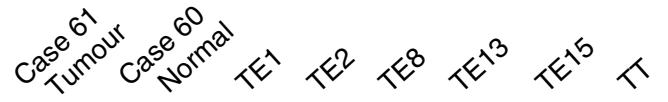

SSCP

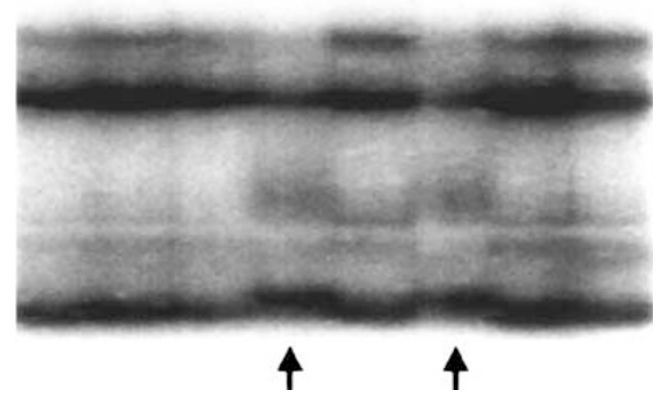

B

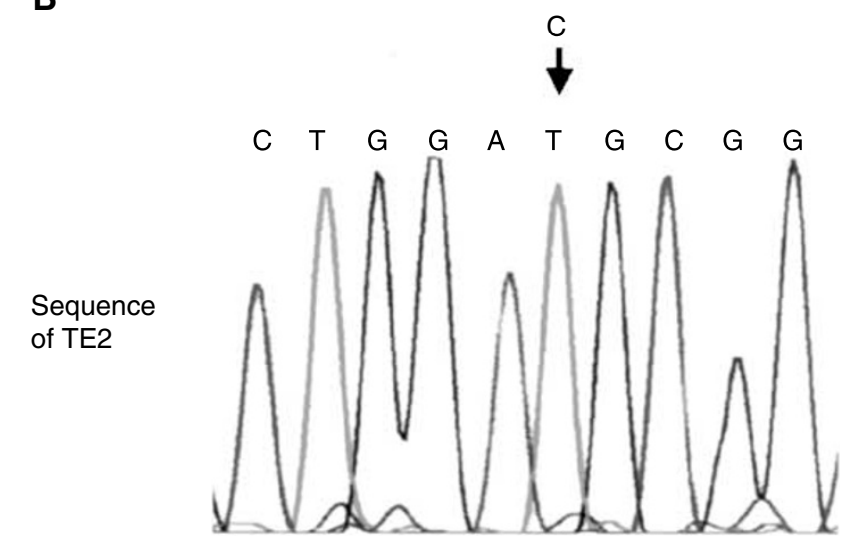

Figure 3 Mutation analysis of Axin. (A) Two aberrant bands of tumour DNA were detected in SSCP (arrow). (B) DNA sequencing of excised and reamplified DNA products of TE2 revealed $C \rightarrow T$ transition in codon 563 without amino-acid substitution. It was judged to be a silent SNP.

tumour cells. In tumour tissues, Axin expression was inversely correlated with depth of invasion, lymph node metastasis, and lymphatic invasion. When we examined the Axin status of tumour cells that had invaded lymph vessels, their Axin expression was reduced or lost in most cases, suggesting that reduced expression of Axin initiates or promotes tumour progression. As Axin is a negative regulator of $\beta$-catenin/TCF-dependent cell proliferation (Kikuchi, 1999) and carcinogenesis (Barker et al, 2000), loss of Axin expression in oesophageal SCC may lead to tumour progression.

Western blotting revealed marked variation in the intensity of Axin expression, corresponding to the results of immunohistochemistry of the tumour tissues. During oesophageal carcinogenesis, some error may occur in the process of Axin protein production. Therefore, Northern blotting was performed to investigate the translation status of each tumour cell line. The status of RNA expression was variable, but the levels of Axin expression were equivalent to those of Axin protein with the exception of the TE8 cell line. That is, six of the cell lines - apart from the TE8 line - had no errors of translation. In these six lines, transcription errors might have occurred, because their intensity of Axin expression was weak compared with that in TE8. Thus, in the TE8 line, some errors might have occurred at the level of translation, or after. Further examination of this possibility will be needed.

Next, PCR-SSCP was performed to examine whether the variation of mRNA expression was derived from any genetic
Table 3 Mutational analysis of Axin gene in oesophageal SCC

\begin{tabular}{|c|c|c|c|c|c|}
\hline Case & Age (year)/gender & Exon & Base change $^{a}$ & aa change & Codon \\
\hline 30 & 66/male & 4 & GI256A & Yes (Arg $\rightarrow$ Cys) & 419 \\
\hline 40 & 54/male & 4 & GI256A & Yes (Arg $\rightarrow$ Cys) & 419 \\
\hline 13 & 64/female & 5 & GI396A & No (Ser $\rightarrow$ Ser $)$ & 485 \\
\hline 15 & 62/male & 5 & GI396A & No (Ser $\rightarrow$ Ser) & 485 \\
\hline 17 & 59/male & 5 & GI396A & No (Ser $\rightarrow$ Ser) & 485 \\
\hline TEl & & 5 & GI396A & No (Ser $\rightarrow$ Ser $)$ & 485 \\
\hline TE2 & & 5 & Cl690T & No $(A s p \rightarrow A s p)$ & 563 \\
\hline TEI3 & & 5 & Cl690T & No $(A s p \rightarrow A s p)$ & 563 \\
\hline
\end{tabular}

amino-acid (aa) positions according to GenBank accession no. AF009674.

alterations of the GSK-3 $\beta$ or $\beta$-catenin binding site of Axin DNA. Five patients showed polymorphisms and three cell lines showed silent mutations in the AXIN1 gene, but no pathogenetic gene mutation was detected. Although the frequency of AXIN1 deletions in medulloblastoma is $12 \%$ (Dahmen et al, 2001) and a similar figure for genetic alterations has been demonstrated in HCC (Satoh et al, 2000), the results of our mutational analysis of oesophageal SCC were different, suggesting that association of AXIN1 mutations with carcinogenesis is rare in oesophageal SCC. Similarly, one previous study detected no mutations in paediatric renal tumours (Miao et al, 2002). However, in addition to allelic losses, inactivation of transcription because of methylation in the promoter region could be responsible for downregulation of Axin. This possibility remains to be examined.

To examine whether Axin regulates only the Wnt- $\beta$-cateninTCF/LEF pathway and determine which factors in this pathway would be good predictors of prognosis, we also analysed relations among Axin, $\beta$-catenin, and GSK-3 $\beta$ using immunohistochemistry and Western blotting. There was no significant association between either Axin and $\beta$-catenin, or between $\beta$-catenin and clinicopathologic factors (data not shown). Furuhashi et al (2001) have reported that Axin facilitates Smad3 activation in the TGF $\beta$ signalling pathway. Ishiguro et al (2001) have reported that transcription of AXIN1 upregulated (AXUD1), a gene induced by $A X I N 1$, is independent of the TCF/LEF complex and that AXUD1 is frequently downregulated in some tumours. Oesophageal SCC may be regulated in a similar manner by an unknown pathway. GSK-3 $\beta$ expression was found to have no association with Axin expression or clinicopathologic factors (data not shown). Thus, there may be other pathways besides the Wnt signalling pathway that participate in carcinogenesis.

In HCC cells, adenovirus-mediated gene transfer of wild-type AXIN1 induces apoptosis, regardless of the existence of AXIN1 mutations (Satoh et al, 2000). Thus, transfer of wild-type Axin might offer a possible approach for gene therapy of oesophageal SCC.

In conclusion, Axin expression appears to be useful for predicting the prognosis of patients with oesophageal SCC, because Axin expression declines with tumour progression. Additional studies will no doubt elucidate the mechanism responsible for loss of Axin expression in tumour cells.

\section{ACKNOWLEDGEMENTS}

We gratefully acknowledge the support of the Department of Biochemistry, Hiroshima University Faculty of Medicine. We thank Professor Akira Kikuchi for generous provision of pcDNA3FLAG/rAxin (full-length). This work was supported in part by a Grant-in-Aid for Scientific Research (A) No. 11307021 from Japan Society for the Promotion of Science. 


\section{REFERENCES}

Akiyama T (2000) Wnt/ $\beta$-catenin signaling. Cytokine Growth Factor Rev 11: 273 - 282, doi: 10.1016/S1359-6101(00)00011-3

Ando N, Iizuka T, Kakegawa T, Isoso K, Watanabe H, Ide H, Tanaka O, Shinoda M, Takiyama W, Arimori M, Ishida K, Tsugane S (1997) A randomized trial of surgery with and without chemotherapy for localized squamous carcinoma of the thoracic esophagus: The Japan Clinical Oncology Group study. J Thorac Cardiovasc Surg 114: 205-209

Barker N, Morin PJ, Clevers H (2000) The Yin-Yang of TCF/beta-catenin signaling. Adv Cancer Res 77: 1-24

Bienz M, Clevers H (2000) Linking colorectal cancer to Wnt signaling. Cell 103: $311-320$

Collard JM, Otte JB, Fiasse R, Laterre PF, De Kock M, Longueville J, Glineur D, Romagnoli R, Reynaert M, Kestens PJ (2001) Skeletonizing en bloc esophagectomy for cancer. Ann Surg 234: 25 - 32

Dahmen RP, Koch A, Denkhaus D, Tonn JC, Sorensen N, Berthold F, Behrens J, Birchmeier W, Wiestler OD, Pietsch T (2001) Deletions of AXIN1, a component of the WNT/wingless pathway, in sporadic medulloblastomas. Cancer Res 61: 7039 - 7043

Furuhashi M, Yagi K, Yamamoto H, Furukawa Y, Shimada S, Nakamura Y, Kikuchi A, Miyazono K, Kato M (2001) Axin facilitates Smad3 activation in the transforming growth factor $\beta$ signaling pathway. Mol Cell Biol 21: 5132 - 5141, doi: 10.1128/MCB.21.15.5132-5141.2001

He TC, Sparks AB, Rago C, Hermeking H, Zawel L, da Costa LT, Morin PJ, Vogelstein B, Kinzler K (1998) Identification of c-MYC as a target of the APC pathway. Science 281: $1509-1512$

Ikeda S, Kishida M, Matsuura Y, Usui H, Kikuchi A (2000) GSK-3betadependent phosphorylation of adenomatous polyposis coli gene product can be modulated by beta-catenin and protein phosphatase $2 \mathrm{~A}$ complexed with Axin. Oncogene 19: 537-545

Ikeda S, Kishida S, Yamamoto H, Murai H, Koyama S, Kikuchi A (1998) Axin, a negative regulator of the Wnt signaling pathway, forms complex with GSK-3 $\beta$ and $\beta$-catenin and promotes GSK-3 $\beta$-dependent phosphorylation of $\beta$-catenin. EMBO J 17: $1371-1384$

Ishiguro H, Tsunoda T, Tanaka T, Fujii Y, Nakamura Y, Furukawa Y (2001) Identification of AXUD1, a novel human gene induced by AXIN1 and its reduced expression in human carcinomas of the lung, liver, colon and kidney. Oncogene 20: 5062 - 5066

Kain SR, Mai K, Parisa S (1994) Human multiple tissue Western blots: a new immunological tool for the analysis of tissue-specific protein expression. Biotechniques 17: $982-987$
Kikuchi A (1999) Roles of axin in the Wnt signaling pathway. Cell Signal 11: 777-788, doi: 10.1016/S0898-6568(99)00054-6

Kishida S, Yamamoto H, Ikeda S, Kishida M, Sakamoto I, Koyama S, Kikuchi A (1998) Axin, a negative regulator of the wnt signaling pathway, directly interacts with adenomatous polyposis coli and regulates the stabilization of beta-catenin. J Biol Chem 18: $10823-10826$

Laurent-Puig P, Legoix P, Bluteau O, Belghiti J, Franco D, Binot F, Monges G, Thomas G, Bioulac-Sage P, Zucman-Rossi J (2001) Genetic alterations associated with hepatocellular carcinomas define distinct pathways of hepatocarcinogenesis. Gastroenterology 120: 1763-1773, doi: 10.1053/ gast.2001.24798

Lin YM, Kato T, Satoh S, Nakamura Y, Furukawa Y (2000) Identification of novel polymorphism in the AXIN1 and CDX-2 genes. J Hum Genet 45: $254-256$

Miao J, Kusafuka T, Udatsu Y, Okada A (2002) Axin, the main component of the Wnt signaling pathway, is not mutated in kidney tumors in children. Int J Mol Med 9: 377-379

Morin PJ, Sparks AB, Korinek V, Barker N, Clevers H, Vogelstein B, Kinzler KW (1997) Activation of beta-catenin-Tcf signaling in colon cancer by mutations in beta-catenin or APC. Science 275: 1787-1790

Nakamura Y (1997) Cleaning up on beta-catenin. Nat Med 3: 499-500

Nishihira T, Hashimoto Y, Katayama M, Mori S, Kuroki T (1993) Molecular and cellular features of esophageal cancer cells. J Cancer Res Clin Oncol 119: $441-449$

Satoh S, Daigo Y, Furukawa Y, Kato T, Miwa N, Nishiwaki T, Kawasoe T, Ishiguro H, Fujita M, Tokino T, Sasaki Y, Imaoka S, Murata M, Shimano T, Yamaoka Y, Nakamura Y (2000) AXIN1 mutations in hepatocellular carcinomas, and growth suppression in cancer cells by virus-mediated transfer of AXIN1. Nat Genet 24: 245-250

Tetsu O, McCormick F (1999) Beta-catenin regulates expression of cyclin D1 in colon carcinoma cells. Nature (London) 398: $422-426$

Webster MT, Rozycka M, Sara E, Davis E, Smalley M, Young N, Dale TC, Wooster R (2000) Sequence variants of axin gene in breast, colon, and other cancers: an analysis of mutations that interfere with GSK3 binding. Gene Chromosomes Cancer 28: $443-453$

Wu R, Zhai Y, Fearon ER, Cho KR (2001) Diverse mechanisms of betacatenin deregulation in ovarian endometrioid adenocarcinomas. Cancer Res 61: $8247-8255$

Zeng L (1997) The mouse fused locus encodes Axin, an inhibitor of the Wnt signaling pathway that regulates embryonic axis formation. Cell 90: 181-192 